Egyptian J. of Phycol. Vol. 7(1), 2006

\title{
PHYSICO-CHEMICAL PROPERTIES AFFECTING PHYTOPLANKTON DIVERSITY AND BACTERIOLOGICAL CHARACTERS IN TERTIARY SEWAGE WATER TREATMENT PLANT.
}

\author{
Gahiza A. Ismail ${ }^{1}$, Wafaa S. Abou El-Kheir', Tarek A. Tawfik ${ }^{3}$, \\ Farid Abou El-Nour ${ }^{2}$ and Doaa M. Hammad ${ }^{3}$. \\ 1- Botany Department, Faculty of Girls, Ain Shams University, Cairo, Egypt \\ 2- Environment Specimen Bank, Nuclear Chemistry Department, Hot Lab Center, \\ AEA, Cairo, Egypt. \\ 3- Central Lab for Environmental Quality Monitoring, National Water Research.
}

\begin{abstract}
The present work was carried out at a tertiary sewage water treatment plant located at El- kattameya city, Cairo, Egypt, for 12 months, January- December 2004. The phytoplankton standing crop decreased from 228.4 cells $\times 10^{5} / \mathrm{L}$ at the oxidation tank during summer to 3.7 cells $\times 10^{5} / \mathrm{L}$ at the effluent tank during autumn. Phytoplankton community was represented by 88 species belonging to 42 genera and 7 classes namely; Cyanophyceae forming $68 \%$ of total phytoplankton standing crop, Chlorophyceae (16.4\%), Bacillariphyceae (13.7\%), Euglenophceae $(1.5 \%)$, on the other hand Xanthopyceae, Cryptophyceae and Dinophyceae were sporadic and poorly represented. The leading phytoplankon species were Phormidium molle, Chamydomonas snowii, Nitzschia pellucida and Euglena gracilis. All these species regarded as eutrophic indicators. The tanks under investigation, especially the oxidation tanks are considered to be eutrophic, with decreasing level of eutrophication towards effluent tank, indicate the improvement of water quality. Bacteriological counts using total fecal and fecal coliform were also determined during winter and summer seasons. Total coliform and fecal coliform densities were much higher at the collector tank than at effluent during both winter and summer seasons. Seasonal variations in chlorophyll a at the four tanks of the sewage water treatment system were $190.5 \mathrm{mg} / \mathrm{L}$ recorded at oxidation tank during summer season, while the lowest content of $7.3 \mathrm{mg} / \mathrm{L}$ was recorded at effluent tank during autumn season. The trophic state index was calculated from chlorophyll a values, the highest value (82.1) was observed at oxidation tank during summer and the lowest one (50.0) was obtained at effluent tank during autumn.
\end{abstract}

\section{Introduction}

Martinez-Delgadillo et al. (2005) carried out a study in a wastewater treatment plant in Mexico that is located in a tropical zone. They found that the high 
temperatures have a negative effect mainly on microorganism's activity, oxygen transfer, and sludge settling properties.

The $\mathrm{pH}$ of wastewater needs to remain between 6 and 9 to protect beneficial organisms. Arauzo and Valladolid (2003) observed that high photosynthetic activity during the periods of proliferation of algae gives rise to an increased $\mathrm{pH}$ more than or equal 8.

Sayg-Basbug and Demirkalp (2004) found that conductivity decreased during the algal blooms and they related that to the biological removal of bicarbonate and calcium.

Dissolved oxygen (DO) in wastewater has a great effect on the characteristics of the water. Wastewater that has DO is called aerobic or fresh. Wastewater that has no DO is called anaerobic or septic, (National Small Flows Clearinghouse, 1997). Inspite of that BOD does not necessarily shows the total amount of organic substances in water because there are some substances that are non biodegradable (resistant to biological degradation), these substances need chemical oxidants to be oxidized, the amount of oxygen decreased in such oxidants referred to as the chemical oxygen demand (COD). COD also indicates the pollution level of a water body as it is related to the organic matter present in the water (WQM, 1999).

Lin (2002) reported that phytoplankton solids (biomass and detritus) were a primary source of suspended solids in the aquaculture wastewater. In an effort to maintain a healthy water system and to minimize algal growth, the United States Environmental Protection Agency (USEPA) recommends that phosphorus levels be kept below $0.1 \mathrm{mg} / \mathrm{l}$ and nitrogen levels be kept below $10 \mathrm{mg} / \mathrm{L}$ (Fried et al., 2003).

Ezzat (2002) reported that from the microbiological point of view, most of the water born pathogens is introduced through fecal contamination of water. Such fecal pollution can introduce a variety of internal (enteric) pathogenic bacteria, viruses and parasites whose presence is linked to a variety of microbial diseases. As a result, a set of indicator micro-organisms has been identified and is now commonly applied to determine the hygienic suitability of water for various uses. Rizzo et al. (2004) found that coliform bacteria was not able to re-grow when the dose of chlorine increased to $0.07 \mathrm{mg} / \mathrm{L}$, chlorine doses higher than $0.2 \mathrm{mg} / \mathrm{L}$ at water source with a low total organic carbon (TOC) content are recommended to control bacterial re-growth in the distribution network.

The pollution level of the Radha Kund pond in Mathura, Uttar Pradesh, India, was determined by Praveen and Sharma (2004) through analyzing some physicochemical properties (temperature, turbidity, $\mathrm{pH}, \mathrm{DO}, \mathrm{BOD}, \mathrm{COD}$ and ammonia content) and microbial population (total coliforms, fecal coliforms, Euglena, Paramecium and Ulothrix) of the Radha Kund water. Results showed that the Radha 
Kund pond is grossly polluted. The use of the water from the Radha Kund pond may cause skin diseases and gastrointestinal problems.

Akbulut and Akbulut (2004) investigated the seasonal distribution of the planktonic organisms and biodiversity according to water quality parameters (DO, EC, salinity, $\mathrm{pH}$, temperature, Secchi depth, and total $\mathrm{N}$ and $\mathrm{P}$ ) and chlorophyll a. An increasing trend in $\mathrm{pH}$ was observed in the late spring. DO and nitrate varied seasonally. High levels of DO strongly correlate with the sharp increase in chlorophyll a levels. Both phosphorus and ammonium were directly related to each other. A total of 175 phytoplanktonic organisms were identified. The most dominant species among Bacillariophyta were Synedra, Navicula, Gomphonema and Cymbella genera. In Sultan Marshes, eutrophication is affected by intensive agricultural impact and other factors.

Phytoplankton succession and primary productivity relevant to the physicochemical characters of the wastewater treatment system of El-Gabal El-Asfar station, Cairo, Egypt, was investigated by Farag-Afaf (2005). The tanks and effluent were typically eutrophic, phytoplankton density attained its maximum at aeration tank and its minimum at primary sedimentation tank. 35 species were recorded belonging to 7 different groups: Chlorophyceae was the first dominant group, followed by Bacillariophyceae, Cyanophyceae was the third dominant group and Euglenophyceae represented the fourth dominant group, Dinophyceae, Cryptophyceae and Xanthophyceae each was represented by one species. Some species like Scenedesmus obliqus, Scenedesmus bijugatus, Chlorella vulgaris, Chlamydomonas snowii and Spirulina platensis were the leading species and were recorded as eutrophic indicators.

The aim of this work is to study the influence of environmental factors existed in the different tanks (collector, oxidation settling and effluent) of the treatment plant on phytoplankton diversity and bacteriological characters. Physico-chemical properties are : air and water temperatures , $\mathrm{pH}, \mathrm{EC}, \mathrm{DO}, \mathrm{COD}, \mathrm{BOD}, \mathrm{TSS}$, total alkalinity, nutrients $\left(\mathrm{No}_{3}, \mathrm{NH}_{3}, \mathrm{Po}_{4}, \mathrm{P}_{2} \mathrm{O}_{4}, \mathrm{P}, \mathrm{N}: \mathrm{P}\right.$ and $\left.\mathrm{Sio}_{2}\right)$ as well as major ions(Ca, $\mathrm{K}, \mathrm{Na}$, $\mathrm{Mg}, \mathrm{Cl}$ and $\mathrm{SO}_{4}$ ) .

\section{Materials and Methods}

Water sampling was carried out according to standard methods for examination of water and wastewater (APHA, 1992). Water samples from the four tanks (collector tank, oxidation tanks, settling tanks and effluent tank) of the tertiary sewage water treatment plant at El-Katameya city, south-east of Cairo, Egypt, for 12 months (January - December 2004 ) were collected in various containers according to the parameters need to be measured. Polyethylene containers of two-liter capacity were 
used for most of chemical analyses, while brown glass containers were used for phosphorus samples. Samples collected for trace metals and cations analyses were preserved by adding concentrated nitric acid to lower $\mathrm{pH}$ below 2 to be protected against microbial reactions.

\section{Collection of phytoplankton samples}

Samples, for identification of phytoplankton, were monthly collected from each tank into 2 liters plastic containers and immediately preserved with buffered formalin (final concentration 4\%). The phytoplankton were removed quantitatively from water by sedimentation process in which organisms were allowed to settle down for 5 days in glass cylinders, and then the supernatant was siphoned off by using a plastic tube ending with phytoplankton cloth of $10 \mu \mathrm{m}$ mesh diameter. The settled cells of final concentration $10 \mathrm{ml}$ were then transferred to small glass vials.

\section{Collection of water samples for bacteriological analyses}

Samples were collected in $500 \mathrm{ml}$ clean sterilized glass containers which were filled to its two-third in order to facilitate mixing by shaking before examination, then closed carefully by its stopper avoiding any external contamination and examined within 6 hours after collection. In the present work samples for bacteriological analyses were collected during winter and summer seasons from both collector and effluent tanks to examine the efficiency of the system under investigation in eliminating total and fecal coliform bacteria in the effluent.

All samples collected for either physical, chemical, biological and bacteriological analyses were stored in an iced cooler box and delivered immediately to the laboratory for analyses.

\section{Physico-chemical and biological parameters}

Physico-chemical analyses were carried out according to standard methods for examination of water and wastewater (APHA, 1992), which including temperature (air \& water), pH, EC, TSS, DO , BOD , COD , $\mathrm{NH}_{3}$ and chlorophyll a, also biological parameters such as phytoplankton and bacteria were determined according to APHA, 1992.

\section{Ortho-phosphate $\left(\mathrm{P}_{2} \mathrm{O}_{4}\right)$}

Orthophosphate values was determined colorimetrically as described by Strickland and parsons (1965). This method depends on the reduction of antimonylphospho-molybdate complex to intense blue color by ascorbic acid. This color is proportional to the phosphorus concentration which was measured at $960 \mathrm{~nm}$.

\section{Total alkalinity}

Total alkalinity $\left(\mathrm{CO}_{3}\right.$ and $\left.\mathrm{HCO}_{3}\right)$ was determined a few hours after collection, by titrating the samples against standard $0.02 \mathrm{~N} \mathrm{H}_{2} \mathrm{SO}_{4}$ and using phenolphthaline and methyl orange as indicators, results was expressed as $m \mathrm{CaCO}_{3}$ and $\mathrm{Ca}\left(\mathrm{HCO}_{3}\right)_{2} / \mathrm{L}$. 
Carbonate was not detected in any of the studied tanks during the annual cycle of the present work.

\section{Major anions}

Chloride $(\mathrm{Cl})$, sulfates $\left(\mathrm{SO}_{4}\right)$, nitrites $\left(\mathrm{NO}_{2}\right)$, nitrates $\left(\mathrm{NO}_{3}\right)$ and phosphates $\left(\mathrm{PO}_{4}\right)$ were measured using Ion chromatography (IC) model DX-500 chromatography system. Nitrite was not detected in the four tanks of the sewage water treatment plant during the whole period of the present work.

\section{Major cations}

Major cations $(\mathrm{Ca}, \mathrm{K}, \mathrm{Mg}$ and $\mathrm{Na})$, phosphorus and silicon metals were measured using the Inductively Coupled Plasma-Emission Spectrometry (ICP-ES) with Ultra Sonic Nebulizer (USN). This Nebulizer decreases the instrumental detection limits by $10 \%$. The ICP is Perkin Elmer optima 3000, USA. The samples were filtered by filtration system through membrane filter of pore size 0.45 um before analyses. The minimum value of 6.95 was detected in the oxidation tank during August; these values are considered suitable for algal growth.

\section{Results}

Seasonal variations of water temperatures were always lower than corresponding values of air temperatures (Table 1). The values of water temperatures ranged between 16.9 as a minimum value in winter and $28.8^{\circ} \mathrm{C}$ as a maximum value in summer. The air temperatures showed a similar pattern, where it fluctuated from 20.7-34.0 $0^{\circ} \mathrm{C}$.

Table (1): Seasonal variations of water and air temperatures $\left({ }^{\circ} \mathrm{C}\right)$ in the four tanks.

\begin{tabular}{|l|c|c|}
\hline \multirow{2}{*}{ Seasons } & \multicolumn{2}{|c|}{ Temperature } \\
\cline { 2 - 3 } & Water & Air \\
\hline Winter & 16.9 & 20.7 \\
\hline Spring & $\mathbf{2 3 . 9}$ & $\mathbf{2 9 . 0}$ \\
\hline Summer & $\mathbf{2 8 . 8}$ & $\mathbf{3 4 . 0}$ \\
\hline Autumn & $\mathbf{2 6 . 9}$ & $\mathbf{3 1 . 0}$ \\
\hline
\end{tabular}

The seasonal variations of physical properties in the four tanks are presented in Table (2). Values of $\mathrm{pH}$ were always towards the alkaline side (> 7). The maximum $\mathrm{pH}$ value of 7.8 was recorded in the effluent tank during winter and autumn, while the minimum value of 7.1 was detected in the oxidation tank during spring; these values are considered suitable for algal growth. Minimum Electric Conductivity (EC) value of $575 \mathrm{umhos} / \mathrm{cm}$ was recorded at the collector tank during spring season, while a 
maximum value of 883 umhos/cm was recorded at the effluent tank during autumn season. Dissolved Oxygen (DO) recorded its minimum value of $0.2 \mathrm{mgO}_{2} / \mathrm{L}$ at the collector tank during summer season on the other hand the maximum DO value of 7.7 $\mathrm{mgO}_{2} / \mathrm{L}$ was detected at the effluent tank during winter. The results showed an increase in DO concentrations towards the effluent tank. The lowest Biochemical Oxygen Demand (BOD) value of $1.0 \mathrm{mgO}_{2} / \mathrm{L}$ was detected in the effluent tank during spring season, while the highest value of $1466.6 \mathrm{mgO}_{2} / \mathrm{L}$ was recorded at oxidation tank during summer season. Chemical Oxygen Demand (COD) lowest and highest values of 16.67 and $11833.3 \mathrm{mgO}_{2} / \mathrm{L}$ were detected at effluent and oxidation tanks respectively during spring season. Total alkalinity lowest and highest values were 150.4 and $319.45 \mathrm{mg} / \mathrm{L}$ detected in settling and collector tanks respectively during autumn season. Total Suspended Solids (TSS) lowest value of $1.7 \mathrm{mg} / \mathrm{L}$ was detected in effluent tank during autumn season; on the other hand a highest value of 7386.67 was determined at the oxidation tank during spring season.

Table (2): Seasonal variations of physical properties in the four tanks.

\begin{tabular}{|c|c|c|c|c|c|c|c|}
\hline \multirow[b]{2}{*}{ Seasons } & \multicolumn{7}{|c|}{ Properties } \\
\hline & pH & EC & DO & BOD & COD & $\begin{array}{c}\text { Total } \\
\text { alkalinity }\end{array}$ & TSS \\
\hline \multicolumn{8}{|c|}{ Collector tank } \\
\hline Winter & 7.4 & 789 & 1.4 & 100.0 & 194.3 & 245.6 & 114.6 \\
\hline Spring & 7.2 & 575 & 0.6 & 230.0 & 412.0 & 258.7 & 294.7 \\
\hline Summer & 7.3 & 595 & 0.2 & \begin{tabular}{|l|l|}
173.3 \\
\end{tabular} & 373.0 & 250.2 & 185.7 \\
\hline Autumn & 7.8 & 872 & 0.6 & 163.3 & 453.0 & 319.4 & 235.3 \\
\hline \multicolumn{8}{|c|}{ Oxidation tank } \\
\hline Winter & 7.5 & 793 & 3.7 & 490.0 & 8300.0 & 212.3 & 6493.3 \\
\hline Spring & 7.1 & 582 & 1.6 & \begin{tabular}{|l|l|}
$\mathbf{9 3 3 . 3}$ \\
\end{tabular} & 11833.3 & 179.4 & 7386.7 \\
\hline Summer & 7.3 & 601 & 1.4 & 1466.6 & 9075.0 & 180.8 & 6693.3 \\
\hline Autumn & 7.2 & 876 & 1.7 & 1000.0 & 7500.0 & 188.5 & 5300.0 \\
\hline \multicolumn{8}{|c|}{ Settling tank } \\
\hline Winter & 7.7 & 795 & 7.2 & 1.6 & 29.3 & 190.3 & 6.3 \\
\hline Spring & 7.3 & 585 & 3.3 & 3.0 & 23.0 & 150.5 & 10.0 \\
\hline Summer & 7.3 & 605 & 2.6 & 6.7 & 29.3 & 156.0 & 6.7 \\
\hline Autumn & 7.7 & 880 & 3.1 & 3.7 & 29.6 & 150.4 & 7.3 \\
\hline \multicolumn{8}{|c|}{ Effluent tank } \\
\hline Winter & 7.8 & 798 & 7.7 & 1.3 & 23.3 & 193.6 & 2.0 \\
\hline Spring & 7.3 & 584 & 4.4 & 1.0 & 16.7 & 160.5 & 4.3 \\
\hline Summer & 7.4 & 608 & 2.7 & 4.3 & 22.7 & 161.9 & 2.6 \\
\hline Autumn & 7.8 & 883 & 2.6 & 2.0 & 17.3 & 150.7 & 1.7 \\
\hline
\end{tabular}


Table (3) shows the seasonal variations of chemical properties in the four tanks. Ammonia lowest value of $0.02 \mathrm{mg} / \mathrm{L}$ was detected in effluent tank during summer season, while a highest value of $28.0 \mathrm{mg} / \mathrm{L}$ was determined at the collector tank during spring season Nitrate lowest value of $0.3 \mathrm{mg} / \mathrm{L}$ was detected in the collector tank during winter season, while a highest value of $20.3 \mathrm{mg} / \mathrm{L}$ was determined at the effluent tank during autumn season. Phosphate lowest value of 4.2 $\mathrm{mg} / \mathrm{L}$ was detected in effluent tank during summer season, while a highest value of $9.41 \mathrm{mg} / \mathrm{L}$ was determined at the collector tank during autumn season. Orthophosphate lowest value recorded $0.8 \mathrm{mg} / \mathrm{L}$ at both settling and effluent tanks during spring season, while a highest value of $1.4 \mathrm{mg} / \mathrm{L}$ was determined at the oxidation tank during both winter \& summer seasons.

Table (3): Seasonal variations of chemical properties, major anions and cations in the four tanks.

\begin{tabular}{|c|c|c|c|c|c|c|c|c|c|c|c|c|c|c|}
\hline \multirow{3}{*}{$\stackrel{\mathscr{N}}{\tilde{E}}$} & \multirow{3}{*}{ 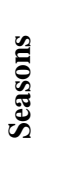 } & \multicolumn{13}{|c|}{ Properties } \\
\hline & & \multicolumn{7}{|c|}{ Chemical properties } & \multicolumn{6}{|c|}{ Major anions and cations } \\
\hline & & $\mathrm{NH}_{3}$ & $\mathrm{NO}_{3}$ & $\mathrm{PO}_{4}$ & $\mathbf{P}_{2} \mathbf{O}_{4}$ & $\mathbf{P}$ & $\mathbf{N}: \mathbf{P}$ & $\mathrm{SiO}_{2}$ & $\mathrm{Ca}$ & $\mathrm{Mg}$ & $\mathbf{N a}$ & $\mathbf{K}$ & Cl & $\mathrm{SO}_{4}$ \\
\hline \multirow{4}{*}{ 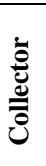 } & W. & 9.7 & 0.3 & 7.2 & 1.3 & 3.0 & 1.2 & 1.9 & 49.4 & 32.2 & 67.2 & 16.7 & 104.5 & 99.7 \\
\hline & Sp. & 28.0 & 1.01 & 7.9 & 1.1 & 3.3 & 2.4 & 1.7 & 28.8 & 12.3 & 44.0 & 15.9 & 54.1 & 60.9 \\
\hline & S. & 6.1 & 3.1 & 5.5 & 1.3 & 2.3 & 1.0 & 2.9 & 31.9 & 9.3 & 48.1 & 13.4 & 55.5 & 64.1 \\
\hline & A. & 16.6 & 1.3 & 9.4 & 1.1 & 3.9 & 1.2 & 2.9 & 19.8 & 129.6 & 56.1 & 18.7 & 98.0 & 112.4 \\
\hline \multirow{4}{*}{ 氮 } & W. & 0.5 & 2.5 & 7.7 & 1.4 & 3.2 & 0.2 & 2.0 & 61.9 & 52.5 & 65.8 & 16.2 & 98.2 & 102.0 \\
\hline & Sp. & 0.9 & 2.5 & 6.4 & 1.1 & 2.6 & 0.3 & 2.4 & 29.9 & 12.4 & 46.2 & 15.8 & 57.7 & 69.1 \\
\hline & S. & 0.3 & 13.8 & 5.9 & 1.4 & 2.4 & 1.4 & 3.1 & 32.1 & 9.1 & 48.4 & 13.2 & 57.4 & 75.1 \\
\hline & A. & 1.1 & 13.6 & 8.9 & 1.1 & 3.7 & 1.0 & 2.8 & 159.7 & 176.0 & 56.4 & 17.9 & 97.3 & 114.0 \\
\hline \multirow{4}{*}{ 恶 } & W. & 0.1 & 3.6 & 5.2 & 1.3 & 2.1 & 0.4 & 2.0 & 76.4 & 67.3 & 67.6 & 15.9 & 99.2 & 103.9 \\
\hline & Sp. & 0.3 & 3.4 & 5.2 & 0.8 & 2.1 & 0.5 & 1.9 & 29.4 & 12.0 & 45.8 & 15.5 & 56.4 & 68.8 \\
\hline & S. & 0.04 & 9.8 & 4.4 & 1.2 & 1.8 & 1.3 & 2.8 & 34.0 & 9.8 & 54.0 & 14.9 & 57.6 & 68.7 \\
\hline & A. & 0.09 & 18.8 & 7.5 & 1.1 & 3.1 & 1.6 & 2.8 & 146.2 & 158.4 & 56.1 & 18.2 & 96.6 & 112.2 \\
\hline \multirow{4}{*}{ 氖 } & W. & 0.06 & 4.9 & 4.7 & 1.3 & 1.8 & 0.6 & 1.8 & 89.9 & 80.1 & 68.5 & 16.5 & 113.0 & 108.9 \\
\hline & Sp. & 0.05 & 4.2 & 4.8 & 0.8 & 1.6 & 0.6 & 1.6 & 30.1 & 12.1 & 46.6 & 15.3 & 57.4 & $\begin{array}{l}68.7 \\
\end{array}$ \\
\hline & S. & 0.02 & 9.3 & 4.2 & 1.2 & 1.5 & 1.3 & 3.3 & 32.1 & 8.7 & 48.2 & 12.5 & 57.5 & 69.9 \\
\hline & A. & 0.06 & 20.3 & 6.5 & 1.2 & 2.2 & 2.0 & 2.8 & 119.9 & 123.2 & 56.7 & 18.5 & 100 & 115.2 \\
\hline
\end{tabular}

W.= Winter, Sp.= Spring, S.= Summer, A.= Autumn. 
Phosphorus lowest value was $1.5 \mathrm{mg} / \mathrm{L}$ recorded at effluent tank during summer season, while the highest value was $3.87 \mathrm{mg} / \mathrm{L}$ determined at the collector tank during autumn season. The $\mathrm{N}: \mathrm{P}$ ratios for the present study ranged between 0.2 as a minimum value determined at the oxidation tank during winter season and 2.4 as a maximum value obtained at the collector tank during spring season. Silicate lowest and highest values were 1.6 and $3.3 \mathrm{mg} / \mathrm{L}$ detected during spring and summer seasons respectively at the effluent tank.

Seasonal pattern of major ions $\left(\mathrm{Ca}, \mathrm{Mg}, \mathrm{Na}, \mathrm{K}, \mathrm{Cl}\right.$ and $\left.\mathrm{SO}_{4}\right)$ showed that their concentrations were lower during both summer and spring seasons rather than in winter and autumn seasons Table (3). Calcium lowest value of $28.8 \mathrm{mg} / \mathrm{L}$ was detected at the collector tank during spring season, while a highest value of 159.7 $\mathrm{mg} / \mathrm{L}$ was determined at oxidation tank during autumn season. Magnesium lowest value of $8.7 \mathrm{mg} / \mathrm{L}$ was detected at the effluent tank during summer season, while a highest value of $176.0 \mathrm{mg} / \mathrm{L}$ was determined at oxidation tank during autumn season. Sodium lowest value of $44.03 \mathrm{mg} / \mathrm{L}$ was detected at the collector tank during spring season, while a highest value of $68.5 \mathrm{mg} / \mathrm{L}$ was determined at effluent tank during winter season. Potassium lowest value of $12.5 \mathrm{mg} / \mathrm{L}$ was detected at the effluent tank during summer season, while a highest value of $18.7 \mathrm{mg} / \mathrm{L}$ was determined at collector tank during autumn season. Chloride lowest value of $54.11 \mathrm{mg} / \mathrm{L}$ was detected at the collector tank during spring season, while a highest value of 113.03 $\mathrm{mg} / \mathrm{L}$ was determined at effluent tank during winter season. Sulfate lowest value of $60.9 \mathrm{mg} / \mathrm{L}$ was detected at the collector tank during spring season, while a highest value of $115.17 \mathrm{mg} / \mathrm{L}$ was determined at effluent tank during autumn season.

\section{Phytoplankton standing crop:}

The phytoplankton community consisted of 88 species belonging to 42 genera representing seven classes namely Cyanophyceae, Chlorophyceae, Bacillariophyceae, Euglenophyceae, Cryptophyceae, Xanthophyceae and Dinophyceae. Phytoplankton standing crop varied widely from 3.7 cells $\times 10^{5} / \mathrm{L}$ as a minimum value at effluent tank during autumn to 228.4 cells $\times 10^{5} / \mathrm{L}$ as a maximum value at the oxidation tank during summer (Table 4). Maximum phytoplankton standing crop and biomass observed in the oxidation tank were attributed to the high concentrations of nutrients and organic matter characterizing this tank, which by turn results in reduced species number, richness and diversity; in addition to the abundance of eutrophic species. Cyanophyceae group is the first dominant group, it is forming $68 \%$ of total phytoplankton standing crop, and represented by 24 species. 
Table (4): Total phytoplankton (individuals $\times 10^{5} / \mathrm{L}$ ) recorded in the four tanks of the study area during different seasons.

\begin{tabular}{|l|c|c|c|c|}
\hline \multirow{2}{*}{ Tanks } & \multicolumn{4}{|c|}{ Seasons } \\
\cline { 2 - 5 } & Winter & Spring & Summer & Autumn \\
\hline Collector & $\mathbf{8 7 . 3}$ & $\mathbf{6 0 . 7}$ & $\mathbf{6 6 . 3}$ & $\mathbf{3 3 . 6}$ \\
\hline Oxidation & $\mathbf{1 4 5 . 2}$ & $\mathbf{1 7 9 . 8}$ & $\mathbf{2 2 8 . 4}$ & $\mathbf{1 1 6 . 8}$ \\
\hline Settling & $\mathbf{1 0 . 4}$ & 11.7 & $\mathbf{1 4 . 3}$ & 10.7 \\
\hline Effluent & $\mathbf{5 . 6}$ & 4.3 & 6.9 & 3.7 \\
\hline Total & $\mathbf{2 4 8 . 5}$ & $\mathbf{2 5 6 . 5}$ & $\mathbf{3 1 5 . 9}$ & $\mathbf{1 6 4 . 8}$ \\
\hline
\end{tabular}

Phormidium molle, phormidium dictyothallum, Spirulina laxissima and Microcystis aeruginosa were the most dominant species. Chlorophyceae was the second dominant group it is forming $16.4 \%$ of total phytoplankton standing crop, and represented by 26 species. Chlamydomonas snowii, Chlorella sp., Chlamydomonas moewusii var. maior, Chlamydomonas globosa and Scenedesmus abundans were the most dominant species. Bacillariophyceae is considered to be the third dominant group, it is represented by 24 species and forming $13.7 \%$ of total phytoplankton standing crop. Nitzschia pellucida, Navicula confervaceae and Nitzschia sublinearis were the most dominant species. Euglenophyceae is the fourth group, it is less dominant compared with other groups, it is represented by 10 species and forming $1.5 \%$ of total phytoplankton standing crop. Euglena gracilis and Euglena pisciformis were the most dominant species. Xanthophyceae, Cryptophyceae and Dinophyceae were poorly represented in the phytoplankton community, Xanthophyceae was represented by 2 species, and on the other side only one species was representing each of Cryptophyceae and Dinophyceae.

\section{Bacteriological Analyses}

Total coliform and fecal coliform densities were much higher at the collector tank than at effluent tank during both winter and summer seasons. It was found that densities of both bacterial types dropped sharply at effluent tank during the two seasons before chlorination or disinfection process with a percent reduction of $99.9 \%$, indicating that the tertiary treatment system under investigation is very effective in eliminating coliform bacteria (Table 5).

\section{Chlorophyll a}

The highest concentration of chlorophyll a was $190.0 \mathrm{mg} / \mathrm{L}$ recorded at oxidation tank during summer season, while the lowest content of $7.3 \mathrm{mg} / \mathrm{L}$ was determined at effluent tank during autumn season. Average values for chlorophyll a ranged between $136.7 \mathrm{mg} / \mathrm{L}$ as a maximum value obtained at oxidation tank and 25.2 $\mathrm{mg} / \mathrm{L}$ as a minimum value recorded for the effluent tank (Table 6). 
Table (5): Variations in Total Coliform and Fecal Coliform counts at the collector and effluent tanks during winter and summer seasons (CFU/100ml).

\begin{tabular}{|c|c|c|c|c|}
\hline \multirow{2}{*}{ Season } & \multicolumn{2}{|c|}{ Collector } & \multicolumn{2}{|c|}{ Effluent } \\
\hline & TC & FC & TC & FC \\
\hline Winter & $850 \times 10^{5}$ & $530 \times 10^{5}$ & $316 \times 10^{5}$ & $195 \times 10^{5}$ \\
\hline Summer & $656 \times 10^{5}$ & $420 \times 10^{5}$ & $220 \times 10^{5}$ & $112 \times 10^{5}$ \\
\hline Average & $753 \times 10^{5}$ & $475 \times 10^{5}$ & $268 \times 10^{5}$ & $153 \times 10^{5}$ \\
\hline
\end{tabular}

Table (6): Seasonal variations of Chlorophyll a $\left(\mathrm{mg} / \mathrm{m}^{2}\right)$ at the three tanks under investigation.

\begin{tabular}{|l|c|c|c|c|}
\hline \multirow{2}{*}{ Season } & \multicolumn{4}{|c|}{ Tanks } \\
\cline { 2 - 5 } & Oxidation & Settling & Effluent & Average \\
\hline Winter & $\mathbf{4 4 3 . 2}$ & $\mathbf{8 2 4 . 5}$ & $\mathbf{1 8 3 7 . 9}$ & $\mathbf{1 0 3 5 . 2}$ \\
\hline Spring & $\mathbf{1 8 6 . 4}$ & $\mathbf{8 1 1 . 7 5}$ & $\mathbf{4 3 9 . 6}$ & $\mathbf{4 7 9 . 2 5}$ \\
\hline Summer & $\mathbf{8 1 8 . 5}$ & $\mathbf{4 4 2 . 9}$ & $\mathbf{5 5 1 . 1 8}$ & $\mathbf{6 0 4 . 1 9}$ \\
\hline Autumn & $\mathbf{4 0 6 . 8}$ & $\mathbf{8 5 . 8}$ & $\mathbf{2 5 8 . 1}$ & $\mathbf{2 5 0 . 2}$ \\
\hline Average & $\mathbf{4 6 3 . 7 3}$ & $\mathbf{5 4 1 . 2 4}$ & $\mathbf{7 7 1 . 7}$ & $\mathbf{5 9 2 . 2 1}$ \\
\hline
\end{tabular}

Trophic state index $\left(\right.$ TSI $\left._{\text {Chl. }}\right)$

Trophic state index is a numerical approach used mainly to classify the trophic state of the lakes (Carlson, 1977 and Schultz, 1985). The index can be computed from chlorophyll a concentration as follows:

TSI $_{\text {Chl. }}=9.81(\mathrm{Ln} \mathrm{Chl} \mathrm{a)}+30.6$

The higher the TSI value, the "older" or more productive the lake is. Lakes with TSI values between 0 and 40 are considered to be oligotrophic, those between 40 and 60 are mesotrophic, and those between 60 and 100 are eutrophic. The trophic state index was calculated from chlorophyll a values and shown in Table (7). The highest TSI value (82.1) was observed at oxidation tank during summer season and the lowest value (50.0) was obtained at effluent tank during autumn season.

Table (7): Trophic State Index (TSI)

\begin{tabular}{|c|c|c|c|c|c|}
\hline \multirow{2}{*}{ Season } & \multicolumn{5}{|c|}{ Tanks } \\
\cline { 2 - 6 } & Collector & Oxidation & Settling & Effluent & Average \\
\hline Winter & 72.8 & 80.6 & 62.9 & 60.5 & 69.2 \\
\hline Spring & 67.5 & 81.0 & 66.9 & 65.9 & 70.3 \\
\hline Summer & 70.8 & 82.1 & 68.7 & 64.9 & 71.6 \\
\hline Autumn & 59.9 & 60.3 & 56.8 & 50.0 & 56.75 \\
\hline Average & 67.75 & 76.0 & 63.8 & 60.3 & 66.96 \\
\hline
\end{tabular}




\section{Discussion}

Water temperatures were always lower than corresponding values of air temperatures. The values of water temperatures ranged between $16.9^{\circ} \mathrm{C}$ as a minimum value in winter and $28.8^{\circ} \mathrm{C}$ as a maximum value in summer. The air temperatures showed a similar pattern, where it fluctuated from $20.7-34.0^{\circ} \mathrm{C}$. These results were in agreement with Farag-Afaf (2005) who recorded relatively low water temperatures during winter months $\left(15.3-20.8^{\circ} \mathrm{C}\right)$ and slightly warm temperatures in summer months $\left(25.1-30.9^{\circ} \mathrm{C}\right)$ in sewage water treatment tanks and effluent of El-Gabal ElAsfar wastewater treatment plant, the author added that these temperature ranges are considered to be suitable for algal growth. In the present study the phytoplankton standing crop was higher in both summer and spring seasons over winter and autumn seasons, which agrees with Farag-Afaf (2005) who found that any increase or decrease in phytoplankton standing crop at all tanks and effluent of El-Gabal El-Asfar treatment plant seemed to be correlated with the fluctuation in water temperature.

Values of $\mathrm{pH}$ were always towards the alkaline side (>7). $\mathrm{pH}$ values ranged between 7.1 and 7.8 in the different tanks of the study area, which are within the normal range $(6.5-8)$ stated by FAO (1985) for irrigation water quality. Also $\mathrm{pH}$ values recorded at different tanks seemed to be suitable for phytoplankton growth, similar findings obtained by Shams El-Din-Nihal (2000); Yousry-Karima (2003) and Farag-Afaf (2005).

Values of EC ranged from 575 to 883 umhos $/ \mathrm{cm}$. Elevated EC values were recorded during both autumn and winter seasons, while during both summer and spring seasons decreased EC values were observed reflecting the higher algal abundance which by turn consumed more soluble ions resulting in lowering EC values. In this aspect Sayg-Basbug and Demirkalp (2004) found that conductivity decreased during the algal blooms and related that to the biological removal of bicarbonate and calcium.

Dissolved oxygen concentrations ranged from $0.2 \mathrm{mgO}_{2} / \mathrm{L}$ to $11 \mathrm{mgO}_{2} / \mathrm{L}$, it was found that dissolved oxygen values were very low at the collector tank during the whole period of the present study, values then increased until reaching their maximum at the effluent tank, which reflecting the efficiency of the treatment system in improving water quality. In this connection EPA (1988) stated that if a good effluent is being produced, it should maintain dissolved oxygen of 2-4 $\mathrm{mg} / \mathrm{L}$, which means that DO in the aeration tank is sufficient to sustain all time the desirable microorganisms. When oxygen becomes low, undesirable micro-organisms may predominate and settleability and the quality of activated sludge may be poor. 
Both BOD and COD concentrations showed a sharp decrease after the biological activated sludge treatment process that occurred in the oxidation tanks, this was emphasized by the reduced BOD and COD concentrations observed at effluent tank with average percentage reduction of $98.7 \%$ and $94.4 \%$ respectively, these findings reflect the effectiveness of the biological process carried out in the treatment system under investigation in removing organic pollution. A negative correlation was observed between dissolved oxygen concentrations and both BOD and COD values, it was also found that the decrease in both BOD and COD concentrations in both settling and effluent tanks was accompanied by a reduction in phytoplankton standing crop, while the highest phytoplankton standing crop was observed in the oxidation tanks where maximum BOD and COD recorded. The present results are in line with those obtained by Farag-Afaf (2005) who found that BOD and COD contents of the treatment tanks and effluent of El-Gabal El-Asfar sewage water treatment station decreased from the primary sedimentation tanks to chlorination tank.

Data revealed that the efficiency of the tertiary sewage water treatment system in reducing TSS concentrations, where maximum values were recorded in both collector and oxidation tanks while minimum levels obtained at both settling and effluent tanks. Effluent average TSS percentage reduction was 98.6\%. High TSS values observed during summer and spring seasons over winter and autumn seasons were associated with the higher phytoplankton standing crop. In this aspect Lin (2002) reported that phytoplankton solids (biomass and detritus) were a primary source of suspended solids in the aquaculture wastewater.

Total alkalinity values appeared to decrease with decreasing the pollution load; where highest levels were recorded at the collector tank, while lowest values were determined at both settling and effluent tanks. These findings were in harmony with Farag-Afaf (2005) who found that total alkalinity levels increased by increasing the different pollutant doses from the chlorination tank to the primary sedimentation tank of El-Gabal El-Asfar sewage water treatment system.

Maximum ammonia concentrations were recorded in the collector tank which constitutes raw sewage water; the values then declined reaching their minimum at the effluent tank with average percentage reduction of $99.6 \%$. It was found that ammonia formed about $91.2 \%$ of the total inorganic nitrogen compounds at the collector tank indicating high pollution level that confirmed by the extremely low dissolved oxygen concentrations. These findings were in line with the following investigators, FaragAfaf (2005) recorded higher ammonia concentrations in the primary sedimentation tank of El-Gabal El-Asfar treatment plant which containing raw sewage water. Shams El-Din- Nihal (2000) found that ammonia formed about $96 \%$ of the total inorganic nitrogen compounds in Attaka sewage water treatment system, and she attributed this 
to the high level of water pollution. Camargo and Alonso (2006) mentioned that Cyanobacteria, dinoflagellates and diatoms appeared to be the major groups that may be stimulated by inorganic nitrogen pollution. Nitrite was absent through out the whole study period, this could be resulted from the nitrification process that occurred in the second oxidation tank, where amounts of oxygen injected in addition to oxygen liberated during photosynthesis of algae were sufficient to oxidize nitrite into nitrate. Seasonal variations in nitrate concentrations in the present investigation revealed that nitrate concentrations increased during and after the biological treatment process, this is because in most of the cases water comes out from the second oxidation tank where aerobic conditions are present (nitrification phase). Regarding phytoplankton community, it was noticed that the increase observed in nitrate levels from the oxidation tank to the effluent tank was accompanied by a reduction in phytoplankton standing crop, which indicated that nitrate concentrations were insufficient to fuel phytoplankton growth, and hence it considered being a limiting factor.

Data revealed that the highest phosphorus levels were observed during autumn season, which could be related to reduced uptake rates by phytoplankton, this was confirmed by the reduced phytoplankton standing crop recorded at the four tanks during autumn season compared to other seasons.. Phytoplankton standing crop remarkably decreased at these tanks during the whole study duration revealing that phytoplankton growth was nitrogen limited rather than phosphorus limited.. The above findings were supported by the N:P ratios ranged between 0.24 as a minimum value at the oxidation tank during winter season and 2.36 as the maximum value at the collector tank during spring season. Both values indicating nitrogen deficiency, and hence it becomes a limiting factor for algal cell growth. It was also noticed that silicate level was lower during spring season than in other seasons, as a consequence of the high flourishing of Bacillariophyceae. The present findings were in agreement with Shams El-Din-Nihal (2000) who found that silicate was not a limiting factor for phytoplankton growth due to its relatively high concentrations.

As mentioned above all of the major ions are required for algal growth and metabolism, this explained the lower concentrations of major ions observed during both summer and spring seasons which were accompanied by the highest phytoplankton standing crop revealing the high utilization rate by algae during their growth peaks. The present results were in line with Farag-Afaf (2005) who attributed most of the decrease recorded in major ions to the consumption by phytoplankton, micro-organisms, chlorophyll synthesis, photosynthesis and metabolic reactions.

Results illustrated in Table (4), revealed that phytoplankton standing crop varied widely from 3.7 cells $\times 10^{5} / \mathrm{L}$ as a minimum value at effluent tank during autumn to 228 . 4 cells $\times 10^{5} / \mathrm{L}$ as a maximum value at the oxidation tank during 
summer, reflecting the hypereutrophic conditions prevailing at the oxidation tank as a consequence of excess nutrients and organic matter. The oxidation tank is characterized by the high phytoplankton standing crop, Chlorophyll a, reduced species number, richness and diversity; in addition to the high densities of tolerant species that were dominating the phytoplankton community. These findings were in line with Farag-Afaf (2005) who found that phytoplankton standing crop major peak was observed at the aeration tanks of El-Gabal El-Asfar sewage treatment plant and attributed that to the hypereutrophic conditions characterizing such tanks.

Regarding the trophic status of the tanks (Table7) and according to Carlson (1977) and Schultz (1985), the tanks under investigation are considered to be eutrophic, with decreasing level of eutrophication towards both settling and effluent tanks. The abundance of Cyanophyceae in the collector tank and Chloroccocales spp. in the oxidation tank with the absence of Desmidialis during the whole course of the present investigation also referred to the eutrophic conditions. Chlorophyll a concentrations (Table 6) were positively correlated with total phytoplankton standing crop in all of the studied tanks during the four seasons. Average values for chlorophyll a ranged between $136.7 \mathrm{mg} / \mathrm{L}$ as a maximum value obtained at oxidation tank and $25.2 \mathrm{mg} / \mathrm{L}$ as a minimum value recorded for effluent tank. Maximum concentration of chlorophyll a together with the highest phytoplankton standing crop was observed at oxidation tank during summer season. In line with our observations was Akbulut and Akbulut (2004) who studied phytoplankton and zooplankton structure of Sultan Marshes in Central Anatolia, they found that chlorophyll a concentrations were correlated with the total phytoplankton and with the increase during summer season.

It was found that coliforms concentrations in wastewater in developing countries are generally higher than those reported from developed countries (Feachem et al., 1981). The present findings were in accordance with the previous investigator, where total coliform bacteria (Table 5) in primary treated sewage water at the collector tank ranged between $850 \times 10^{5} \mathrm{CFU} / 100 \mathrm{ml}$ during winter and $656 \times 10^{5}$ CFU/100ml during summer, while fecal coliform bacteria ranged between $530 \times 10^{5}$ $\mathrm{CFU} / 100 \mathrm{ml}$ during winter and $420 \times 10^{5} \mathrm{CFU} / 100 \mathrm{ml}$ during summer. In the present investigation total coliform (TC) and fecal coliform (FC) bacteria were examined once during winter season and once during summer season at both collector and effluent tanks. Concentrations of TC and FC in the collector tank were very high during both seasons (Table 5), with a relative increase of coliform densities in winter over that in summer. George et al. (2002) measured fecal coliform abundance in raw and treated sewage; he concluded that removal of culturable FC was the most efficient in treatments with high retention time in an activated sludge process with nitrification and denitrification, lagooning, in biofiltration and in the treatment with a 
Physico-chemical properties affecting phytoplankton diversity and bacteriological characters in

tertiary disinfection step. Ezzat (2002) reported that considerable public health risk can be associated from dealing with water contaminated with fecal coliform >200 CFU/100ml.

\section{References}

Akbulut, N. and Akbulut, A. (2004). Phytoplankton and zooplankton structure of Sultan Marshes in Central Anatolia. Hacettepe J. Biology and Chemistry, 33: 31-40.

American Public Health Association "APHA" (1992). Standard methods for the examination of water and wastewater (18th ed.), Washington, DC, USA.

Arauzo, M. and Valladolid, M. (2003). Short-term harmful effects of unionized ammonia on natural populations of Moina micrura and Brachionus rubens in a deep waste treatment pond. Water Res. Oxford, 37(11): 2547-2554.

Carlson, R. E. (1977). A trophic state index of the lakes. Limnol. Oceanogr., 22(2): 361-369.

Camargo, J. A. and Alonso, A. (2006). Ecological and toxicological effects of inorganic nitrogen pollution in aquatic ecosystems: A global assessment. Environ. Int., 32(6): 831-49.

Donatelle, R. J. (2005). Health: The Basics. 6th ed. San Francisco: Pearson Education, Inc.

EPA (1988). Operation of WWTP (2). Environmental Protection Agency, Washington, D.C, USA, 389.

Ezzat, S. M. (2002). Microbial flora and chemical composition of River Nile water at different sites in Egypt. M.Sc. Thesis, Microbiology Dept. Fac. of Science, Ain-Shams University, Egypt.

FAO (1985). Water quality for agriculture. R.S. Ayers and D.W. Westcot. Irrigation and Drainage Paper 29 Rev. 1. FAO, Rome. 174.

Farag-Afaf, H. A. (2005). Studies on the algal flora and physico-chemical parameters in sewage water treatment system (El-Gabal El-Asfar). Ph.D.Thesis, Faculty of Girls, Ain Shams University, Egypt.

Feachem, R. G.; Bradley, D. J.; Garelick, H. and Mara, D. D. (1981). Health aspect of excreta and sludge management. A State of the Art. Review, appropriate technology of water supply and sanitation. Vol.3 Washington, D.C. The World Bank, Transportation, Water and Telecommunication Department, John Wiley and Sons, Inc.

Fried, S.; Mackie, B. and Nothwehr, E. (2003). Nitrate and phosphate levels positively affect the growth of algae species found in Perry Pond. Tillers, 4: 21-24. 
George, I.; Crop, P. and Servais, P. (2002). Fecal coliform removal in wastewater treatment plants studied by plate counts and enzymatic methods. Water Res., 36(10): 2607-17.

Lin, Y. F.; Jing, S. R.; Lee, D.Y. and Wang, T.W. (2002). Removal of solids and oxygen demand from aquaculture wastewater with a constructed wetland system in the start-up phase. Water Environ. Res., 74(2): 136-141.

Martinez-Delgadillo, S. A.; Morales-Mora, M. A.; Rodriguez-Rosales, M. G. and Aquilar-Lopez, R. (2005). The effect of temperature on the performance of a biological wastewater treatment system of a petrochemical company. Ingenieria Hidraulica en Mexico, 20(4): 33-42.

National Small Flows Clearinghouse (1997). Basic wastewater characteristics. Pipeline, 8(4): 2-6 (Fall).

Nakhla, G. F.; Lugowski, A.; Sverdlikov, A.; Scherbina, G. and Babcock, K. (2005). Simultaneous nitrification-denitrification and clarification in a pseudoliquified activated sludge system. Water Environ. Res., 77(1): 98112.

Praveen, K. and Sharma, H. B. (2004). Studies on fluctuating trends in some aquatic micro-organisms of Radha Kund at Mathura, Uttar Pradesh. Flora and Fauna Jhansi, 10(1): 22-24.

Rizzo, L.; Belgiorno, V. and Napoli, R. M. (2004). Regrowth evaluation of coliform bacteria injured by low chlorine doses using selective and nonselective media. J. Environ. Sci. Health A Tox. Hazard Subst. Environ. Eng., 39(8): 2081-92.

Sayg-Basbug, Y. and Demirkalp, F.Y. (2004): Trophic status of shallow Yenicaga Lake (Bolu, Turkey) in relation to physical and chemical environment. Fresenius Environ. Bull., 13(5): 385-393.

Schultz, D. (1985). Lake Green Wood and Boyd Mill Pond algal growth potential test. Environmental Service Division, Ecology Branch, US, EPA, Athens, Ga.

Shams El-Din-Nihal, G. (2000). Phytoplankton variation and productivity in a sewage water treatment system (Suez-Egypt). Ph.D. Thesis, Faculty of Girls, Ain Shams University, Egypt.

Strickland, J. and Parson, T. (1965). A manual of sea water analysis. $2^{\text {nd }}$ ed. Fisheries Research Board of Canada, Ottawa.

WQM Report (1999). Annual report on water quality monitoring of upper and lower lakes Bhopal. Volumes I and II. 
Physico-chemical properties affecting phytoplankton diversity and bacteriological characters in ........

Yousry-Karima, M. (2003). Effect of the relationship between physico-chemical characteristics of water and phytoplankton growth on Lake Nasser water quality. M.Sc. Thesis, Fac. of Girls, Ain-Shams University, Egypt.

\title{
دراسة العوامل الفيزيوكيميائية على تنوع الهائمات النباتية والصفات البكتريولوجية بمحطة معالجة ثلاثية للصرف الصحى الصياتية
}

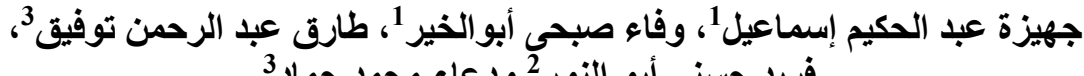

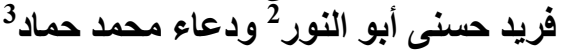

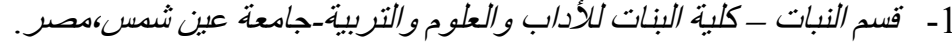

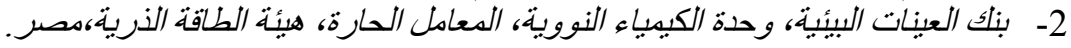

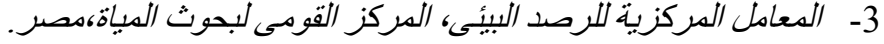

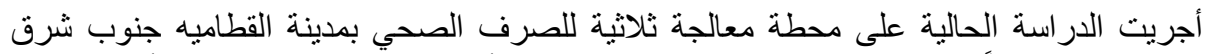

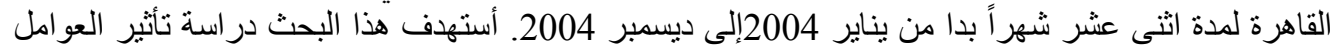

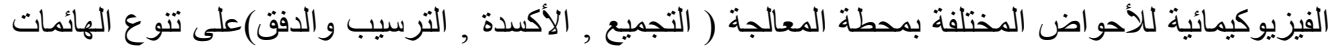

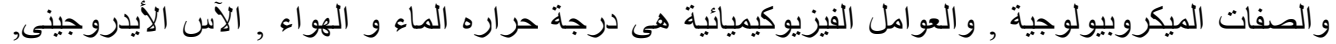

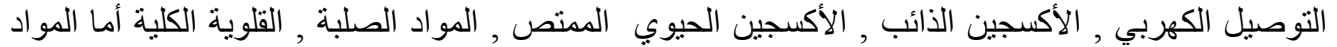
المغذية وهى : النتريت , النترات , الفوسفات , الأرثوفوسفات , الفسفور, السليكات وقد تم أيضا در استة الأملاح

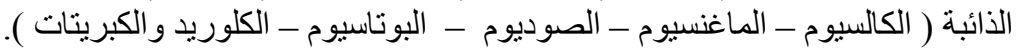

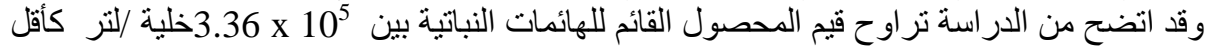

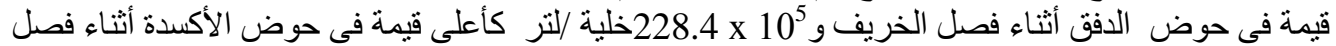

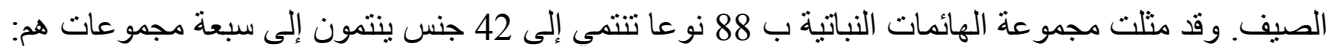

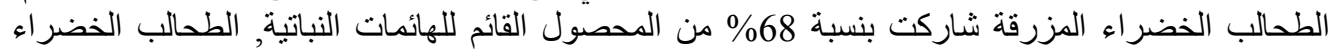

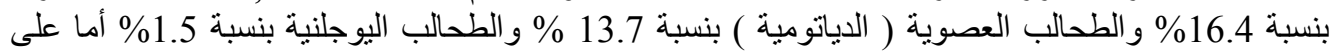

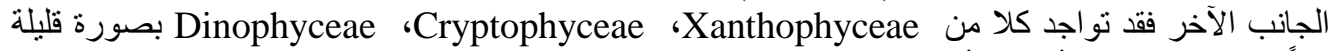

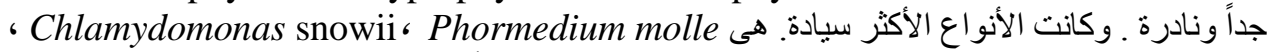
إناً

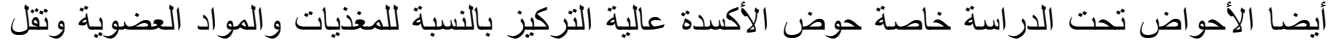

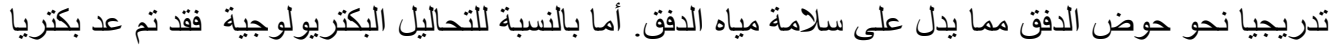

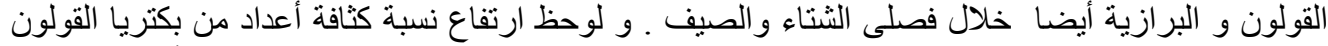

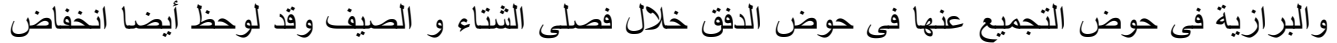

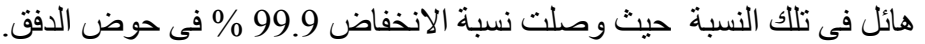

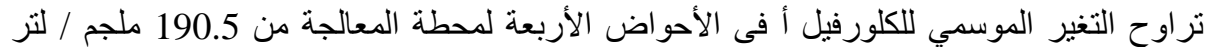

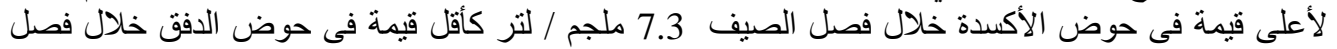

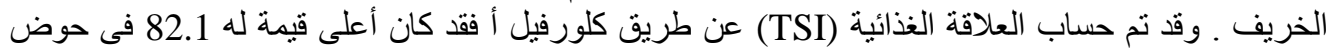
الأكسدة خلال فصل الصيف و أقل قيمة 50.5 فى حوض الذئ الدفق خلال فصل الخريف . 